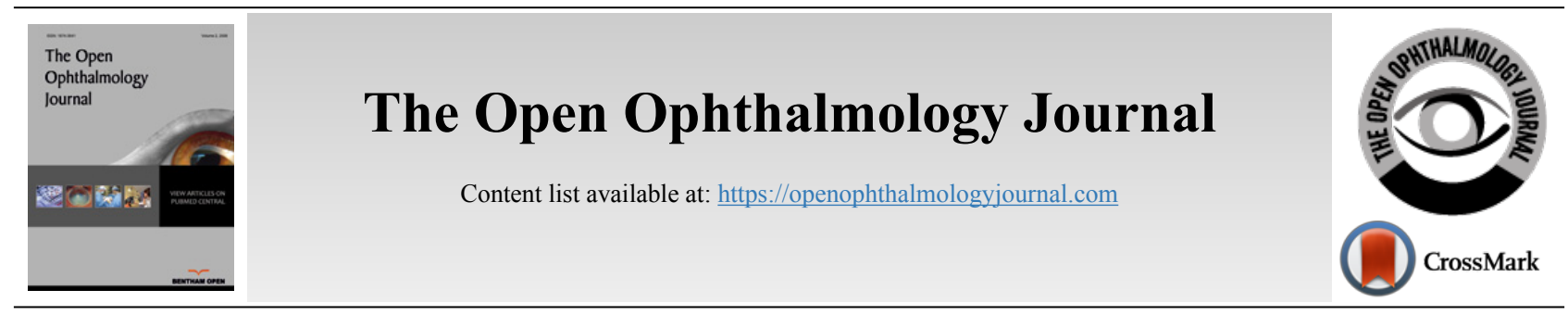

RESEARCH ARTICLE

\title{
Evaluation of Corneal Endothelium after Myopic Laser-Assisted In Situ Keratomileusis (LASIK) with Accelerated Cross-Linking (CXL) in Diabetic Patients
}

\author{
Mohamed Salah El-Din Mahmoud, ${ }^{1, *}$, Ebtesam E. Hassan ${ }^{2}$ and Ahmed S. Abdelhalim ${ }^{1}$ \\ ${ }^{1}$ Department of Ophthalmology, Faculty of Medicine, Minia University, Minia, Egypt \\ ${ }^{2}$ Department of Public Health, Faculty of Medicine, Minia University, Minia, Egypt
}

\begin{abstract}
:
Purpose:

To study the effect of LASIK with accelerated CXL on corneal endothelium in myopic diabetic patients.

Methods:

A prospective comparative interventional case series study on 120 eyes of 60 myopic patients treated with LASIK with accelerated CXL. They were divided into two groups; group A included 60 eyes of diabetic patients, group B included 60 eyes of non-diabetic patients. Corneal endothelium was evaluated by specular microscope preoperatively and after 3 and 6 months postoperatively.

Results:

The endothelial cells density (ECD) showed statistically significant changes after 3 and 6 months postoperatively (p-value $<0.001$ ) in group A while group B showed statistically significant changes after 3 months without significant change after 6 months ( $p$-value $=0.103$ ), both groups had improved to near preoperative levels, with no significant differences between them at the end of 6 months follow-up ( $p$-value $=0.219$ ). Regarding pleomorphism, there was a significant change in group A during 6 months follow-up ( $p$-value $<0.001$ ) with no significant change in group B (pvalue $=0.884$ ), and in comparing both groups, there was a significant change at the end of 6 months follow-up (p-value $<0.001$ ). Regarding polymegathism, there was a significant change in group A during 6 months follow-up (p-value $<0.001$ ) with no significant change in group B after $3(p$-value $=0.178)$ and $6(p$-value $=0.866)$ months follow-up, and in comparing both groups, there was a significant change at the end of 6 months follow-up (p-value $<0.001)$.

Conclusion:

LASIK with accelerated CXL is safe on corneal endothelium in diabetic myopic patients but needs to follow up for a long period.
\end{abstract}

Keywords: Lasik, Corneal endothelium, Accelerated cross-linking, Diabetes mellitus, Diabetic patients, In situ.

\begin{tabular}{|l|l|l|l|}
\hline Article History & Received: August 8, 2021 & Revised: October 14, 2021 & Accepted: November 12, 2021
\end{tabular}

\section{INTRODUCTION}

Laser-in situ keratomileusis (LASIK) is considered the most common form of refractive surgery performed nowadays and provides stable refractive and visual results but has uncommon but potentially dangerous complications such as post-LASIK ectasia. The exact mechanism of post-LASIK ectasia is unknown, but it is thought that the formation of a corneal flap during the LASIK procedure weakens the corneal

\footnotetext{
Address correspondence to this author at the Department of Ophthalmology, Faculty of Medicine, Minia University, Minia, Egypt; Tel: 01003321802;

E-mail: Mohamed_Zaki@mu.edu.eg
}

biomechanical structure, causing post-LASIK ectasia in some cases $[1,2]$.

Corneal collagen cross-linking (CXL) acts by increasing the chemical bonds between collagen fibers of the cornea with an increase in mechanical stiffness with stoppage of progression of keratoconus and post-LASIK ectasia [3, 4]. Simultaneous LASIK and accelerated CXL (LASIK Xtra) have recently been proposed as a way to reduce the risk of postLASIK ectasia and regression [5 - 7].

Although not yet FDA approved, LASIK Xtra is used in many countries around the world and is frequently performed 
on patients who are at high risk of post-LASIK regression, such as those with high degrees of myopia, younger patients, and those with low residual stromal bed thickness [8 - 10]

The cornea is kept all the time in a state of continuous dehydration via the active fluid pump and barrier function in the corneal endothelium. Any disturbance in these activities leads to the affection of the corneal transparency [11].

Diabetes mellitus (DM) is considered one of the most morbid chronic diseases affecting millions of patients all over the world [12]. DM could reduce ECD and the percentage of hexagonal cells but increase coefficient of variation (CV), indicating that diabetes causes the corneal endothelial cell to be unstable [13].

The specular microscope is a useful non-contact instrument that can image corneal endothelium under very high magnification. It can also be used for the measurement of corneal thickness [14].

Our study analyzed the effect of LASIK Xtra on corneal endothelium in diabetic myopic patients by specular microscopy.

\section{MATERIALS AND METHODS}

In a prospective comparative interventional case series study, 120 eyes of 60 myopic patients were treated with LASIK and accelerated CXL at the International Eye Centre and Roaa Laser Vision Correction Centre between October 2019 and March 2021 January; they were divided into 2 groups:

\section{Group A: Involved 60 eyes of 30 diabetic patients}

Group B: Involved 60 eyes of 30 nondiabetic patients. Approval of the ethical committee of the Minia faculty of medicine was obtained, and after a thorough overview of the study's benefits and risks, each patient signed an informed written consent form.

\subsection{Inclusion Criteria}

Age more than 18 years with stable refraction (within 0.5 dioptre (D) for 1 year or more before LASIK surgery), the degree of myopia not more than $-8 \mathrm{D}$ with astigmatism of less than $-5 \mathrm{D}$, and the pachymetry not less than $480 \mu \mathrm{m}$, the Keratometric readings: from $41 \mathrm{D}$ to $48 \mathrm{D}$, we included patients with borderline CCT or residual stromal bed in both groups, no signs of diabetic retinopathy with normal Fluorescein angiography (FA) with no retinal ischemia and without any microaneurysm and normal Optical coherence tomography (OCT) study with normal macular thickness and without macular odema in group A with normal blood glucose level and HbAlc.

\subsection{Exclusion Criteria}

Presence of systemic diseases other than DM, e.g., hypertension, autoimmune diseases, patients with a history of ocular surgery and ocular trauma, myopia more than $-8 \mathrm{D}$, corneal topographic evidence of keratoconus or forme fruste keratoconus (Abnormal elevation back with steep or high Keratometric readings more than $48 \mathrm{D}$ ), corneal thickness less than $480 \mu \mathrm{m}$. Patients with abnormal blood glucose and high HbA1c were excluded from group A. Also, patients with abnormal findings in FA as retinal non-perfusion and any microaneurysm and abnormal findings in OCT as macular odema and epiretinal membrane were excluded.

\subsection{Investigations}

1- Rotating Scheimpflug camera and placido disc (Oculus Optikgeräte GmbH, Wetzlar, Germany) to assess corneal topography and corneal thickness.

2- Specular microscopy (NIDEK, CEM-530, and Japan) was done preoperatively, 3 months, and 6 months postoperatively.

3- FA (Topcon TRC-50IX Mydriatic Retinal Camera, JAPAN) was done to detect early signs of diabetic retinopathy.

4- OCT (Optovue, Inc., Fremont, California) for assessment of the macula.

\subsection{Surgical Procedure}

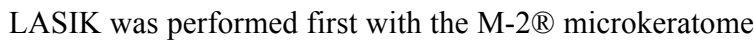
(Moria, France) to create a 110 um flap that was reflected, followed by stromal ablation with the excimer laser (Visex Abbott Star S4 IR). The stromal bed was instilled with 0.1 percent riboflavin in a 20 percent hydroxymethyl propyl cellulose solution (vibex rapid, Avedro Inc, USA) for 2 minutes before the flap was returned to its original location according to the alignment marks. For 3 minutes, the cornea was exposed to UV-A light with a wavelength of 366-374 nm and an irradiance of $30 \mathrm{~mW} / \mathrm{cm} 2$ (OMNI, MMD, USA).

Postoperative treatment was topical antibiotic for one week, a topical anti-inflammatory for 2 weeks, and topical artificial lubricant for one month or more as needed.

Specular microscopy was done at 3 and 6 months postoperatively for assessment of ECD, which was identified on the printed report by cell density (CD), polymegathism, which was identified on the printed report by the coefficient of variation $(\mathrm{CV})$, and rate of pleomorphism which was identified on the printed report by hexagonal cells (HEX).

\subsection{Statistical Analysis}

Statistical analysis was done using IBM SPSS version 21. The statistically significant differences between group A and group B were tested using an independent sample t-test, while within the same group, comparing the repeated measures using paired t-test. A P-value of less than 0.05 was considered as a cut-off for significance.

\section{RESULTS}

\subsection{Demographic Data}

120 eyes of 60 myopic patients were included in the study. They were divided into 2 groups; group A included 60 eyes of 30 diabetic patients (18 males and 12 female) with a mean age of 19-35 years (25.2 \pm 4.49$)$, group B included 60 eyes of 30 nondiabetic patients ( 11 male and 19 female) with a mean age of 19-37 years $(28.13 \pm 5.72)$. 


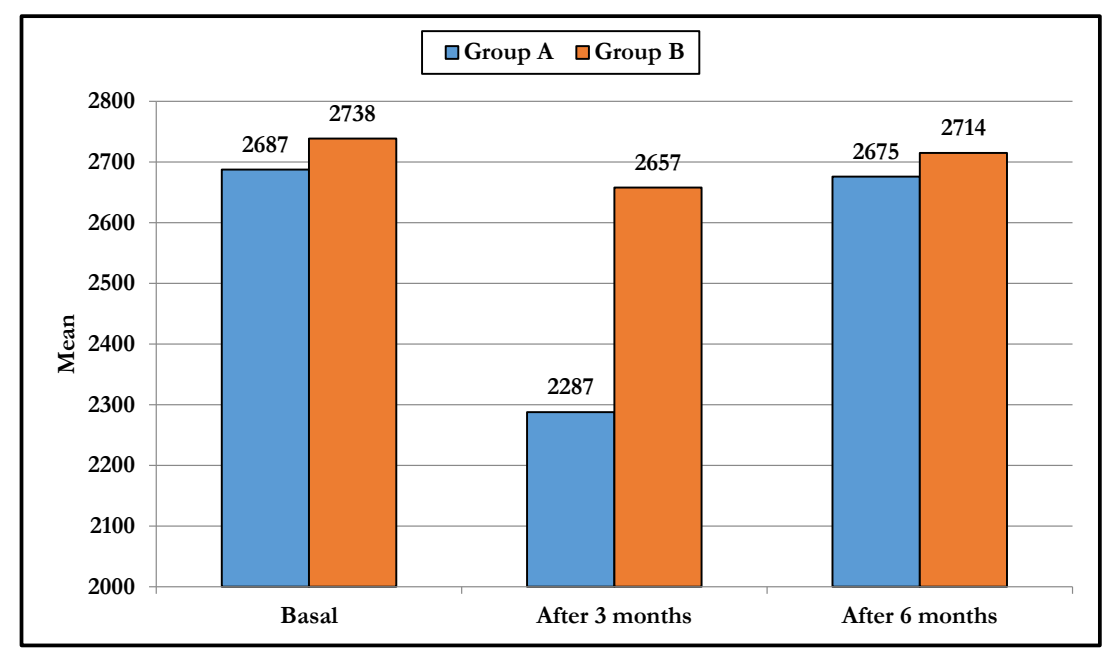

Fig. (1). ECD changes in group A, the ECD decreased significantly after 3 months and improved after 6 months while the changes in group $\mathbf{B}$ were less than group $\mathbf{A}$.

\subsection{Preoperative Patients' Data}

The preoperative sphere, cylinder, uncorrected distance visual acuity (UCDVA), best corrected distance visual acuity (BCDVA), kearometric readings (K1 and $\mathrm{K} 2$ ), and central corneal thickness (CCT) are summarized in Table $\mathbf{1}$.

\subsection{ECD}

The mean preoperative ECD was $2687.5 \pm 165 \mathrm{CD} / \mathrm{mm}^{2}$ in group A and $2738.7 \pm 197 \mathrm{CD} / \mathrm{mm}^{2}$ in group B. At 3 months postoperatively, both groups had a statistically significant decrease in mean ECD ( $p$-value $<0.001)$, with no significant change in group B after 6 months and significant change in group A with no significant difference on comparing both groups (p-value $=0.219)$ at the end of 6 months follow-up (Table 2 and Fig. 1).

\subsection{Pleomorphism}

There was a statistically significant decrease in pleomorphism in group $\mathrm{A}$ at 3 months and 6 months postoperatively compared to the preoperative value ( $p$ value $<0.001$ ), and a statistically significant decrease in pleomorphism in group B at 3 months with no significant changes at 6 months ( $p$-value $=0.884$ ) and on comparing both groups, there were significant differences at 3 and 6 months (pvalue $<0.001$ ) (Table 3 and Fig. 2).

Table 1. The preoperative patients' data.

\begin{tabular}{|c|c|c|c|}
\hline- & Group A & Group B & p-value \\
\hline Sphere & $-6.48 \pm 2.75$ & $-6.96 \pm .92$ & 0.366 \\
\hline Cylinder & $-1.90 \pm .31$ & $-1.92 \pm .32$ & 0.998 \\
\hline UCDVA & $.98 \pm .05$ & $.96 \pm .03$ & 0.978 \\
\hline BCDVA & $.007 \pm .02$ & $.010 \pm .03$ & 0.647 \\
\hline K1 & $41.60 \pm 1.13$ & $41.40 \pm 1.01$ & 0.551 \\
\hline K2 & $42.58 \pm 1.04$ & $42.62 \pm .99$ & 0.869 \\
\hline CCT & $514.20 \pm 7.14$ & $498.63 \pm 84.27$ & 0.318 \\
\hline
\end{tabular}

Table 2. ECD evaluation at preoperative and postoperative periods. Notice the major difference in diabetic patients with a mild change in the non-diabetic patients.

\begin{tabular}{|c|c|c|c|}
\hline- & Group A & Group B & p-value \\
\hline Basal & $2687.5 \pm 165$ & $2738.7 \pm 197$ & 0.127 \\
\hline After 3 months & $2287.8 \pm 241$ & $2657.8 \pm 188$ & $<0.001$ \\
\hline After 6 months & $2675.8 \pm 164$ & $2714.9 \pm 181$ & 0.219 \\
\hline p-value & & & \\
\hline Basal vs 3m & $<0.001$ & $<0.001$ & \\
\hline Basal s 6m & $<0.001$ & 0.103 & \\
\hline 3m s 6m & $<0.001$ & $<0.001$ & \\
\hline
\end{tabular}


Table 3. Pleomorphism preoperatively and postoperatively in both groups.

\begin{tabular}{|c|c|c|}
\hline- & Group A & Group B \\
\hline Basal & $40.53 \pm 4.50$ & $46.7 \pm 7.3$ \\
\hline After 3 months & $37 \pm 4.2$ & $44.6 \pm 7.3$ \\
\hline After 6 months & $39.9 \pm 4.28$ & $46.8 \pm 6.9$ \\
\hline p-value & & $<0.001$ \\
\hline Basal vs 3m & $<0.001$ & $<0.001$ \\
\hline Basal vs 6m & $<0.001$ & $<0.001$ \\
\hline 3m vs 6m & $<0.001$ & 0.884 \\
\hline
\end{tabular}

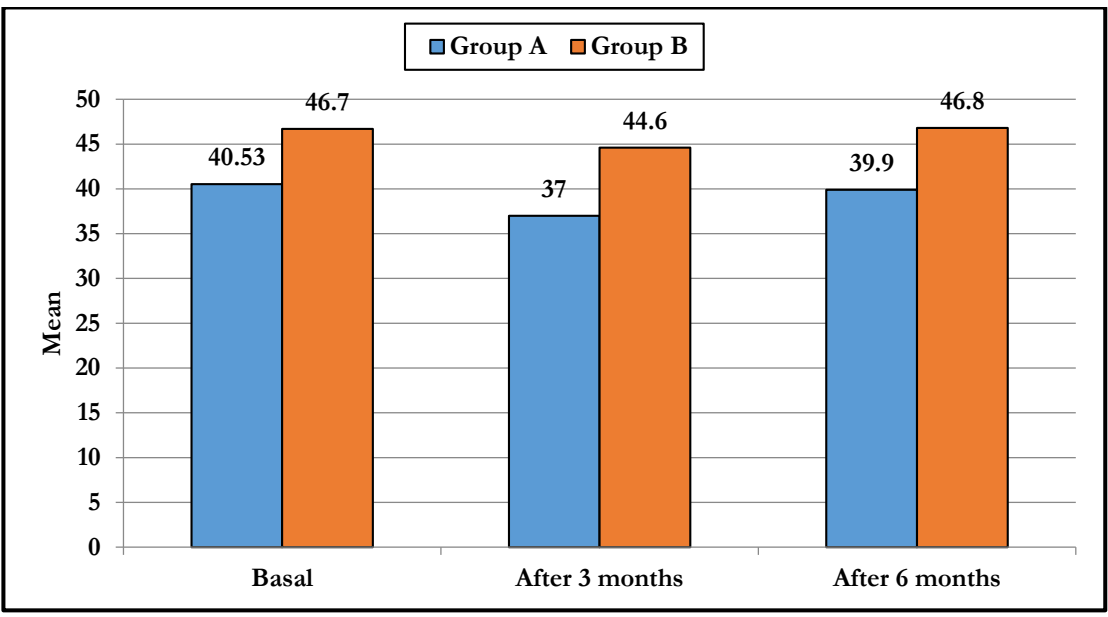

Fig. (2). Changes in pleomorphism were lower in group $\mathbf{A}$ than in group $\mathbf{B}$.

\subsection{Polymegathism or CV}

Preoperatively, group A had a mean polymegathism of $42.6 \pm 6.5$, and group B had a mean polymegathism of $36.6 \pm 5.3$, with a significant difference. There was a statistically significant difference in preoperative value and 3 and 6 months postoperative value in group A, while in group B, there was no statistically significant difference throughout the follow-up period. There was a statistically significant difference after 6 months between both groups (p-value $<0.001$ ) (Table 4 and Fig. 3).

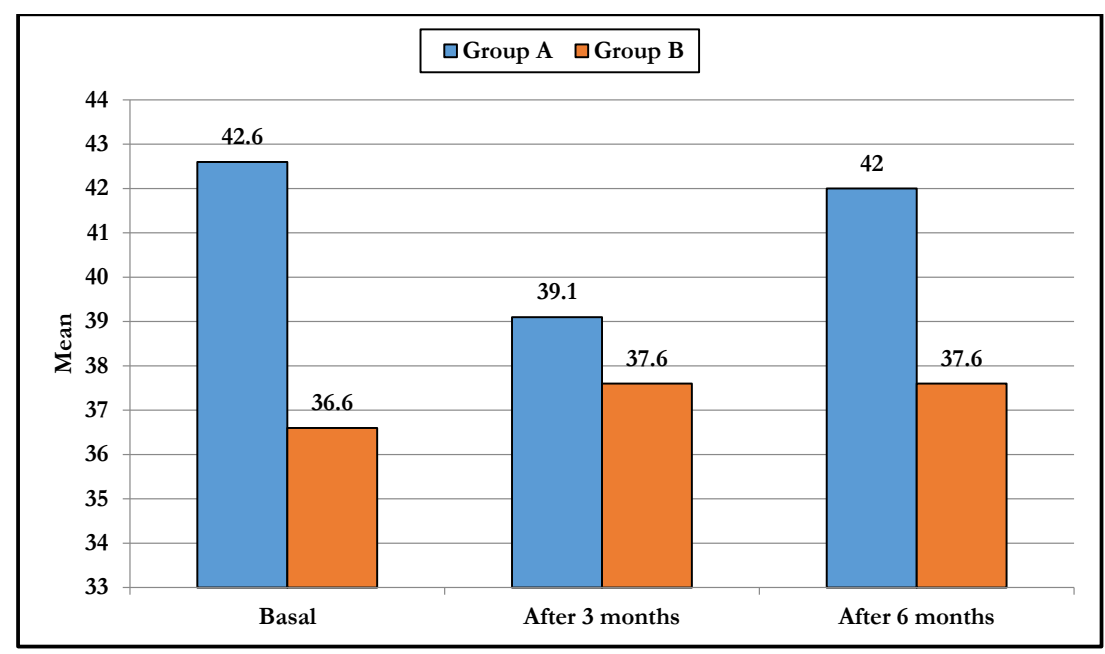

Fig. (3). $\mathrm{CV}$ values were higher in group $\mathbf{A}$ than group $\mathbf{B}$. 
Table 4. CV preoperatively and postoperatively in both groups.

\begin{tabular}{|c|c|c|c|}
\hline & Group A & Group B & p-value \\
\hline Basal & $42.6 \pm 6.5$ & $36.6 \pm 5.3$ & $<0.001$ \\
\hline After 3 months & $39.1 \pm 6.6$ & $37.6 \pm 4.5$ & 0.151 \\
\hline After 6 months & $42.0 \pm 6.4$ & $37.6 \pm 5.1$ & $<0.001$ \\
\hline p-value & & & \\
\hline Basal vs 3m & $<0.001$ & 0.070 & \\
\hline Basal vs 6m & $<0.001$ & 0.178 & \\
\hline 3m vs 6m & $<0.001$ & 0.866 & \\
\hline
\end{tabular}

\section{DISCUSSION}

Postoperative ectasia is considered a rare but visually debilitating problem after LASIK in some myopic patients, particularly moderate to high myopia in young patients, so LASIK is a major challenge in these patients. Hence, the combined application of simultaneous accelerated CXL and LASIK is used to reduce the risk of Post-LASIK ectasia and regression [15].

But the corneal endothelium is affected to some extent by accelerated CXL; the energy of UV-A is $3 \mathrm{~mW} / \mathrm{cm}^{2}$, which was used for $30 \mathrm{~min}$ together with hydrophilic riboflavin $0.1 \%$ application resulting in up to $95 \%$ decrease in energy of UV-A reaching the corneal endothelium in the standard $\mathrm{CXL}$ treatment. To reduce the procedure period, $9 \mathrm{~mW} / \mathrm{cm}^{2}$ for $10 \mathrm{~min}$ or $30 \mathrm{~mW} / \mathrm{cm}^{2}$ for $3 \mathrm{~min}$ are used which is equal to $3 \mathrm{~mW} / \mathrm{cm}^{2}$ for $30 \mathrm{~min}$. The high dose of UV-A light energy damages the sub-basal nerve plexus, harming the endothelial pump function $[16,17]$.

DM affects all structural layers of the cornea, including the corneal epithelium, corneal nerves, tear film, and corneal endothelium, with morphological and functional changes and an increased risk of endothelial complications after intraocular surgery. Although the pathophysiological mechanisms behind diabetic corneal endothelium damage are still unknown, osmotic damage owing to excessive sorbitol build up and oxidative damage due to glycation end-product accumulation have both been implicated [18].

The endothelium has been studied in both diabetic patients and healthy people in a number of researches. The corneal endothelium of diabetic individuals alters morphologically, according to the majority of them. In type $2 \mathrm{DM}$ patients, other investigations found a significant drop in ECD and hexagonality, as well as an increase in CV. Several investigations, however, reported no change between diabetic and non-diabetic participants' ECDs. The impact of DM on the corneal endothelium is still up for debate [19].

Nowadays, LASIK is considered a relative contraindication in diabetic patients due to the pathologic changes in the cornea of these patients. Also, the immune response is weak, and wound healing is delayed with the need for more follow-up in these patients [20,21].

On the other side, some studies revealed that corneal complications after LASIK did not increase in patients with well-controlled DM and the visual outcomes between the diabetic and non-diabetic patients showed no significant difference, so LASIK could be performed safely in only selected cases provided that DM is well controlled with no ocular or systemic complications as nephropathy or peripheral neuropathy according to the American Academy of Ophthalmology recommendations [22, 23].

Most studies on diabetic patients showed that the cornea has more thickness, more polymegathism, and less pleomorphism than non-diabetic patients; these changes could be correlated to the duration of diabetes and/or the metabolic control status [24, 25].

Our study studied the effect of accelerated CXL on corneal endothelium in diabetic myopic patients in comparison with non-diabetic myopic patients. In reviewing the literature, we found no previous studies on the effect of LASIK Xtra on corneal endothelium in diabetic patients. 120 eyes with borderline CCT or residual stromal bed were evaluated, 60 eyes had DM with normal blood glucose level and HbAlc. Complete ocular examination was done to exclude ocular complications of DM; also FA and OCT were done to exclude early retinal affection.

In the non-diabetic population, there was no significant change in the mean ECD by the end of the 6-month follow-up period ( $p$-value $=0.103)$, but there was a significant change in the diabetic group ( $\mathrm{p}$-value $<0.001$ ). Furthermore, when both groups were compared, there was no substantial difference $(\mathrm{p}$ value $=0.219$ ) at the end of 6 months follow-up. These findings agreed with other studies on the effect of CXL and refractive surgery on the corneal endothelium.

Regarding pleomorphism, there were significant changes in the diabetic patients at the end of 6 months follow-up (pvalue $<0.001$ ) with no significant changes in the non-diabetic group ( $p$-value $=0.884$ ), our study showed that no significant differences between both groups preoperatively and postoperatively at 6 months ( $p$ value $<0.001$ ).

$\mathrm{CV}$ represents an indicator of the uniformity of endothelial cell size. In the diabetic group, there was a significant change between the preoperative value and after 6 months postoperatively ( $p$-value $<0.001$ ) while no significant change in the non-diabetic group after 6 months of surgery ( $p$-value= 0.178 ), there is a significant difference preoperatively and postoperatively at 6 months on comparing both groups (pvalue $<0.001$ ).

During the follow-up period, we noticed stable postoperative refraction without cases of post LASIK ectasia or regression, which was the main indication of associated crosslinking with LASIK (Figs. 4 and 5). 


\begin{tabular}{|c|c|c|c|}
\hline \multirow{9}{*}{$\begin{array}{c}000 \\
\because 0 \\
0\end{array}$} & Ninber of Cells (MU) & cells & 84 \\
\hline & Cell Density $(C O)$ & cells $/ \mathrm{mm}^{2}$ & 2841 \\
\hline & Average Area (AVG) & $\mu \mathrm{m}^{2}$ & 352 \\
\hline & Standard Deviation (100) & $\mu \mathrm{m}^{2}$ & 126 \\
\hline & Coefficient of Variation (CV) & $\%$ & 38 \\
\hline & Uax Area (WAX) & $\mu \mathrm{m}^{2}$ & 895 \\
\hline & Vin Area $(\mathbf{V I N})$ & $\mu \mathrm{m}^{2}$ & 131 \\
\hline & Hexagonal Cells (HEX) & $\%$ & 54 \\
\hline & Corneal Thickness (CT) & $\mu \mathrm{m}$ & 513 \\
\hline
\end{tabular}

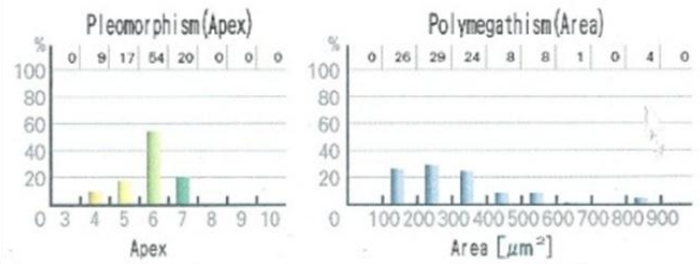

\begin{tabular}{|c|c|c|c|}
\hline \multirow{5}{*}{ 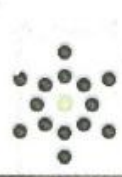 } & Number of Cells (NN) & cells & 132 \\
\hline & Call Density $(00)$ & $\mathrm{cel} / \mathrm{s} / \mathrm{mm}^{2}$ & 2174 \\
\hline & Average Area (AMG) & $\mu \mathrm{m}^{2}$ & 460 \\
\hline & Standard Deviation (SO) & $\mu \mathrm{m}^{2}$ & 148 \\
\hline & Coefficient of Variation (CV) & $\%$ & 34 \\
\hline & Vix Area (UAX) & $\mu \mathrm{m}^{2}$ & 1223 \\
\hline & Vin Area (VIN) & $\mu \mathrm{m}^{2}$ & 135 \\
\hline & Hexagonal Cells (HEX) & $\%$ & 65 \\
\hline & Corneal Thickness (CT) & $\mu \mathrm{m}$ & 442 \\
\hline
\end{tabular}
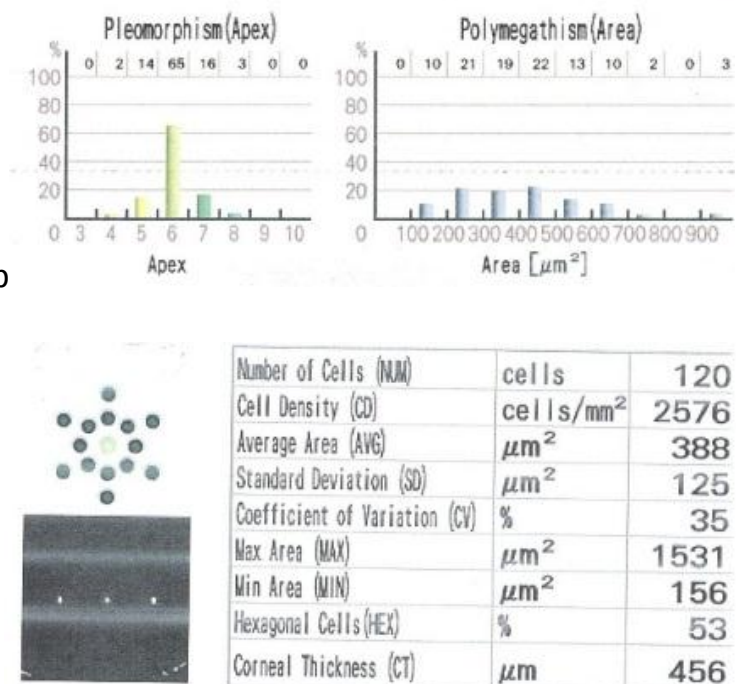

\begin{tabular}{|l|l|r|}
\hline Nunber of Cells (MM) & cells & 120 \\
\hline Cell Density (CD) & cel Is $/ \mathrm{mm}^{2}$ & 2576 \\
\hline Average Area (AVG) & $\mu \mathrm{m}^{2}$ & 388 \\
\hline Standard Deviation (SO) & $\mu \mathrm{m}^{2}$ & 125 \\
\hline Coefficient of Variation (CV) & $\%$ & 35 \\
\hline Nax Area (MaX) & $\mu \mathrm{m}^{2}$ & 1531 \\
\hline Vin Area (MIN) & $\mu \mathrm{m}^{2}$ & 156 \\
\hline Hexagonal Cells(IEX) & $\%$ & 53 \\
\hline Corneal Thickness (CT) & $\mu \mathrm{m}$ & 456 \\
\hline
\end{tabular}
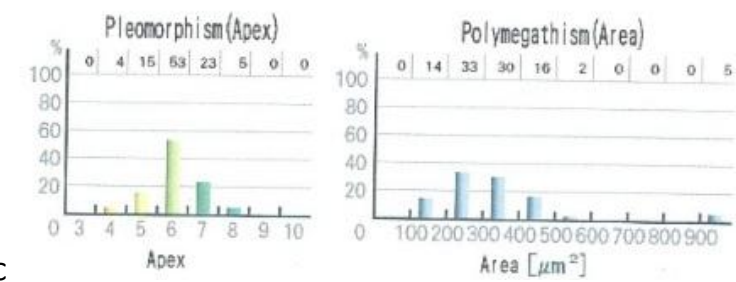

Fig. (4). Specular microscopy in the diabetic group. The cell density (CD) was decreased significantly after 3 months. Pleomorphism was represented by hexagonal cells (HEX), which changed markedly after 3 months, and polymegathism, which was represented by CV changed significantly at 3 and 6 months. (a: preoperative- b:after 3 months- c: after 6 months). 


\begin{tabular}{|c|c|c|c|}
\hline \multirow{5}{*}{ 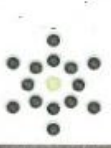 } & Nenber of Cells (NUV) & cells & 208 \\
\hline & Cell Density (CO) & $\mathrm{cel} / \mathrm{s} / \mathrm{mm}^{2}$ & 2975 \\
\hline & Average Area (AVG) & $\mu \mathrm{m}^{2}$ & 336 \\
\hline & Standard Deviation (5D) & $\mu \mathrm{m}^{2}$ & 90 \\
\hline & Coefficient of Variation $(\mathrm{CV})$ & $\%$ & 28 \\
\hline & Vax Area (YXX) & $\mu \mathrm{m}^{2}$ & 944 \\
\hline & Vin Area (VIN) & $\mu \mathrm{m}^{2}$ & 132 \\
\hline & Hexagonal Calls (HEX) & $\%$ & 65 \\
\hline & Conneal Thickness (CT) & $\mu \mathrm{m}$ & 522 \\
\hline
\end{tabular}
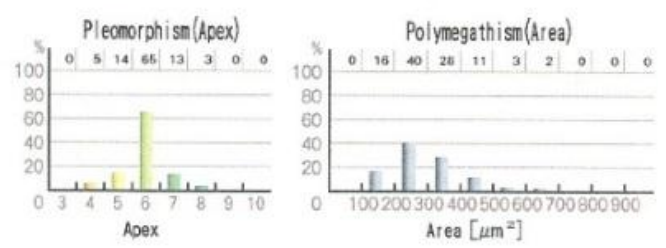

a

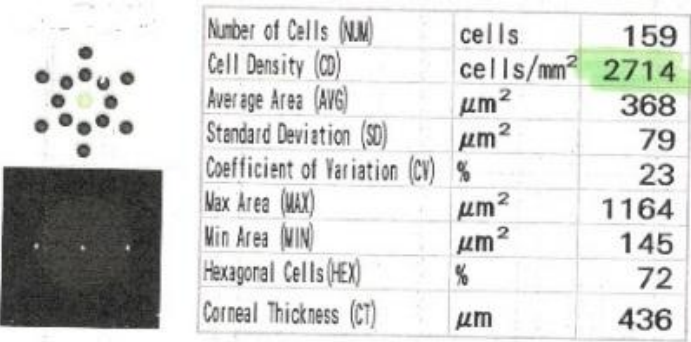

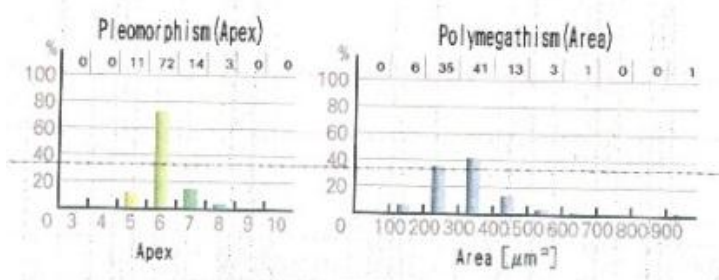

b
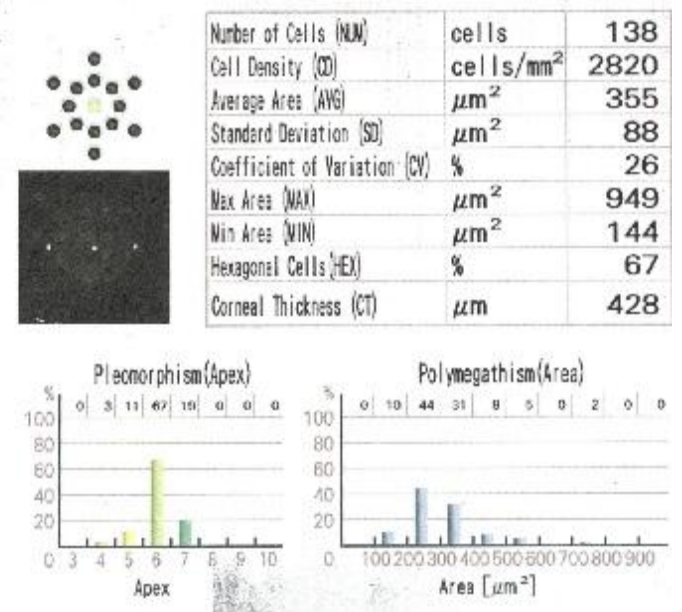

Fig. (5). Specular microscopy in the non-diabetic group. Notice the fewer changes in CD, pleomorphism (HEX), and polymegathism (CV) (a: preoperative- b: after 3 months- c: after 6 months).

Similar research, such as Tohamey M's study on the effect of LASIK Xtra in non-diabetic patients, found that accelerated cross-linking had no significant effect on corneal endothelium during 6 months follow-up [26].Also, a study was done by $\mathbf{W u}$ 
Y which concluded that ECD did not differ between LASIK and LASIK Xtra in non-diabetic patients [17].

Also, our results were consistent with other studies of the effect of LASIK Xtra, although there were some changes in the parameters of the irradiance as Cingü et al. who studied the effect of accelerated CXL $(18 \mathrm{~mW} / \mathrm{cm} 2)$ for 5 minutes and found that ECD decreased postoperatively then returned to the preoperative value at 6 months, while $\mathrm{CV}$ returned to their preoperative value only at 3 months [27]. Another study by Bhandari used more power of UVA irradiance $(30 \mathrm{~mW} / \mathrm{cm} 2)$ for 3 minutes and found that ECD and $\mathrm{CV}$ changed significantly up to 12 months follow-up [28].

Other studies on the effect of accelerated cross-linking in keratoconus and Post-LASIK ectasia as Badawi et al., who used UV-A irradiance of $30 \mathrm{~mW} / \mathrm{cm}^{2}$ for $3 \mathrm{~min}$ and found that the changes in ECD and CV were persistent up to 12 months follow-up [29]. Kanellopoulos compared standard CXL $\left(3 \mathrm{~mW} / \mathrm{cm}^{2}\right.$ for $\left.30 \mathrm{~min}\right)$ in one eye and accelerated CXL $\left(7 \mathrm{~mW} / \mathrm{cm}^{2}\right.$ for $\left.15 \mathrm{~min}\right)$ in the fellow eye of 21 patients and found that there were no significant changes in the corneal endothelium between accelerated and standard CXL [30].

\section{CONCLUSION}

LASIK with accelerated cross-linking is safe on the corneal endothelium count and morphology in diabetic patients, and this potentiates the use of LASIK Xtra in the diabetic myopic patient's especially in high errors but more prolonged follow-up was needed to ensure long-term safety.

\section{LIMITATIONS}

The research has some drawbacks, such as a limited sample size, a short follow-up time, and the lack of distinction between type 1 and type 2 DM.

\section{ETHICS APPROVAL AND CONSENT TO PARTICIPATE}

This study was approved by the Institutional Review Board and Research Ethics Committee of Minia University, Egypt, under approval no. (631-6/2020).

\section{HUMAN AND ANIMAL RIGHTS}

No animals were used in this research. All human research procedures followed were in accordance with the ethical standards of the committee responsible for human experimentation (institutional and national) and with the Helsinki Declaration of 1975, as revised in 2013.

\section{CONSENT FOR PUBLICATION}

Informed consent was obtained from the participants.

\section{STANDARDS OF REPORTING}

STROBE guidelines and methodologies have been followed in this study.

\section{AVAILABILITY OF DATA AND MATERIALS}

The data supporting findings of this study is available from corresponding author [M.S.M.], upon reasonable request.

\section{FUNDING}

None.

\section{CONFLICT OF INTEREST}

The authors declare no conflict of interest, financial or otherwise.

\section{ACKNOWLEDGEMENTS}

Declared none.

\section{REFERENCES}

[1] Jaycock PD, Lobo L, Ibrahim J, Tyrer J, Marshall J. Interferometric technique to measure biomechanical changes in the cornea induced by refractive surgery. J Cataract Refract Surg 2005; 31(1): 175-84. [http://dx.doi.org/10.1016/j.jcrs.2004.10.038] [PMID: 15721710]

[2] Binder PS. Analysis of ectasia after laser in situ keratomileusis: Risk factors. J Cataract Refract Surg 2007; 33(9): 1530-8.

[http://dx.doi.org/10.1016/j.jcrs.2007.04.043] [PMID: 17720066]

[3] Salgado JP, Khoramnia R, Lohmann CP, Winkler von Mohrenfels C. Corneal collagen crosslinking in post-LASIK keratectasia. $\mathrm{Br} \mathrm{J}$ Ophthalmol 2011; 95(4): 493-7.

[http://dx.doi.org/10.1136/bjo.2010.179424] [PMID: 20679077]

[4] Kanellopoulos AJ, Binder PS. Management of corneal ectasia after LASIK with combined, same-day, topography-guided partial transepithelial PRK and collagen cross-linking: The athens protocol. J Refract Surg 2011; 27(5): 323-31.

[http://dx.doi.org/10.3928/1081597X-20101105-01]

[PMID: 21117539]

[5] Rajpal RK, Wisecarver CB, Williams D, et al. Lasik Xtra((R)) provides corneal stability and improved outcomes. Ophthalmol Ther 2015; 4(2): 89-102.

[http://dx.doi.org/10.1007/s40123-015-0039-x] [PMID: 26499330]

[6] Kanellopoulos AJ, Asimellis G. Combined laser in situ keratomileusis and prophylactic high-fluence corneal collagen crosslinking for high myopia: Two-year safety and efficacy. J Cataract Refract Surg 2015; 41(7): 1426-33

[http://dx.doi.org/10.1016/j.jcrs.2014.10.045] [PMID: 26287881]

[7] Kanellopoulos AJ, Kahn J. Topography-guided hyperopic LASIK with and without high irradiance collagen cross-linking: Initial comparative clinical findings in a contralateral eye study of 34 consecutive patients. J Refract Surg 2012; 28(11)(Suppl.): S837-40. [http://dx.doi.org/10.3928/1081597X-20121005-05]

[PMID: 23447898]

[8] Lim EWL, Lim L. Review of laser vision correction (LASIK, PRK and smile) with simultaneous accelerated corneal cross-linking - longterm results. Curr Eye Res 2019; 44(11): 1171-80.

[http://dx.doi.org/10.1080/02713683.2019.1656749]

[PMID: 31411927]

[9] O'Brart DP, Kwong TQ, Patel P, McDonald RJ, O'Brart NA. Longterm follow-up of riboflavin/ultraviolet A $(370 \mathrm{~nm})$ corneal collagen cross-linking to halt the progression of keratoconus. Br J Ophthalmol 2013; 97(4): 433-7.

[http://dx.doi.org/10.1136/bjophthalmol-2012-302556] [PMID: 23385632]

[10] Tan J, Lytle GE, Marshall J. Consecutive laser in situ keratomileusis and accelerated corneal cross-linking in highly myopic patients: Preliminary results. Eur J Ophthalmol 2014; 25(2): 101-7. [http://dx.doi.org/10.5301/ejo.5000543]

[11] Sahu PK, Das GK, Agrawal S, Kumar S, Kumar N. Comparative evaluation of corneal endothelium in diabetic patients undergoing phacoemulsification. Middle East Afr J Ophthalmol 2017; 24(4): 195-201.

[http://dx.doi.org/10.4103/meajo.MEAJO_212_16] [PMID: 29422754]

[12] Ali BA, Salman AG, Mohamad AA, et al. Evaluation of central corneal thickness as measured by pentacam and retinal and choroidal thickness as measured by optical coherence tomography before and after uneventful cataract phacoemulsification in normal and diabetic patients without retinopathy. J Egypt Ophthalmol Soc 2018; 111: 37-42.

[http://dx.doi.org/10.4103/ejos.ejos_12 18] 
[13] Fernández-Muñoz E, Zamora-Ortiz R, Gonzalez-Salinas R. Endothelial cell density changes in diabetic and nondiabetic eyes undergoing phacoemulsification employing phaco-chop technique. Int Ophthalmol 2019; 39(8): 1735-41.

[http://dx.doi.org/10.1007/s10792-018-0995-y] [PMID: 30056522]

[14] Asfuroglu Y, Kemer OE, Kemer O. Central corneal thickness and corneal volume changes in eyes with and without pseudoexfoliation after uneventful phacoemulsification. Int Ophthalmol 2019; 39(2): 275-80.

[http://dx.doi.org/10.1007/s10792-017-0804-z] [PMID: 29260501]

[15] Woodward MA, Randleman JB, Russell B, Lynn MJ, Ward MA, Stulting RD. Visual rehabilitation and outcomes for ectasia after corneal refractive surgery. J Cataract Refract Surg 2008; 34(3): 383-8. [http://dx.doi.org/10.1016/j.jcrs.2007.10.025] [PMID: 18299061]

[16] Kymionis GD, Diakonis VF, Kalyvianaki M, et al. One-year follow-up of corneal confocal microscopy after corneal cross-linking in patients with post laser in situ keratosmileusis ectasia and keratoconus. Am J Ophthalmol 2009; 147(5): 774-778, 778.e1.

[http://dx.doi.org/10.1016/j.ajo.2008.11.017] [PMID: 19200532]

[17] Wu Y, Tian L, Wang LQ, Huang YF. Efficacy and safety of LASIK combined with accelerated corneal collagen cross-linking for myopia: Six-month study. BioMed Res Int 2016; 20165083069 [http://dx.doi.org/10.1155/2016/5083069] [PMID: 27689082]

[18] Lutty GA. Effects of diabetes on the eye. Invest Ophthalmol Vis Sci 2013; 54(14)ORSF81-7

[http://dx.doi.org/10.1167/iovs.13-12979] [PMID: 24335073]

[19] Kim YJ, Kim TG. The effects of type 2 diabetes mellitus on the corneal endothelium and central corneal thickness. Sci Rep 2021; 11(1): 8324.

[http://dx.doi.org/10.1038/s41598-021-87896-3] [PMID: 33859349]

[20] Fraunfelder FW, Rich LF. Laser-assisted in situ keratomileusis complications in diabetes mellitus. Cornea 2002; 21(3): 246-8. [http://dx.doi.org/10.1097/00003226-200204000-00002] [PMID: 11917170]

[21] Halkiadakis I, Belfair N, Gimbel HV. Laser in situ keratomileusis in patients with diabetes. J Cataract Refract Surg 2005; 31(10): 1895-8. [http://dx.doi.org/10.1016/j.jcrs.2005.03.075] [PMID: 16338557]
[22] Cobo-Soriano R, Beltrán J, Baviera J. LASIK outcomes in patients with underlying systemic contraindications: A preliminary study. Ophthalmology 2006; 113(7): 1118.e1-8.

[http://dx.doi.org/10.1016/j.ophtha.2006.02.023] [PMID: 16647130]

[23] Pershing S, Morrison DE, Hernandez-Boussard T. Cataract surgery complications and revisit rates among three states. Am J Ophthalmol 2016; 171: 130-8

[http://dx.doi.org/10.1016/j.ajo.2016.08.036] [PMID: 27615607]

[24] El-Agamy A, Alsubaie S. Corneal endothelium and central corneal thickness changes in type 2 diabetes mellitus. Clin Ophthalmol 2017; 11: 481-6.

[http://dx.doi.org/10.2147/OPTH.S126217] [PMID: 28280298]

[25] Shih KC, Lam KS, Tong L. A systematic review on the impact of diabetes mellitus on the ocular surface. Nutr Diabetes 2017; 7(3)e251 [http://dx.doi.org/10.1038/nutd.2017.4] [PMID: 28319106]

[26] Tohamy MA, Salah M, Sabry AM, et al. Corneal endothelial changes after laser-assisted in situ keratomileusis combined with high-fluence cross-linking. Egypt J Cataract Refract Surg 2018; 24: 42-6. [http://dx.doi.org/10.4103/JCRS.JCRS_3_19]

[27] Cingü AK, Sogutlu-Sari E, Cinar Y, et al. Transient corneal endothelial changes following accelerated collagen cross-linking for the treatment of progressive keratoconus. Cutan Ocul Toxicol 2014; 33(2): 127-31.

[http://dx.doi.org/10.3109/15569527.2013.812107] [PMID: 23859485]

[28] Bhandari V, Lohia M, Reddy JK, et al. Effect of accelerated corneal collagen cross-linking (CXL) on corneal endothelium. Adv Ophthalmol Vis Syst 2015; 3(1): 00074 [http://dx.doi.org/10.15406/aovs.2015.03.00074]

[29] Badawi AE. Corneal endothelial changes after accelerated corneal collagen cross-linking in keratoconus and post LASIK ectasia. Clin Ophthalmol 2016; 10: 1891-8.

[http://dx.doi.org/10.2147/OPTH.S113412] [PMID: 27757009]

[30] Kanellopoulos AJ. Long term results of a prospective randomized bilateral eye comparison trial of higher fluence, shorter duration ultraviolet A radiation, and riboflavin collagen cross linking for progressive keratoconus. Clin Ophthalmol 2012; 6: 97-101. [http://dx.doi.org/10.2147/OPTH.S27170] [PMID: 22275813]

\section{(C) 2021 Mahmoud et al.}

This is an open access article distributed under the terms of the Creative Commons Attribution 4.0 International Public License (CC-BY 4.0), a copy of which is available at: https://creativecommons.org/licenses/by/4.0/legalcode. This license permits unrestricted use, distribution, and reproduction in any medium, provided the original author and source are credited. 